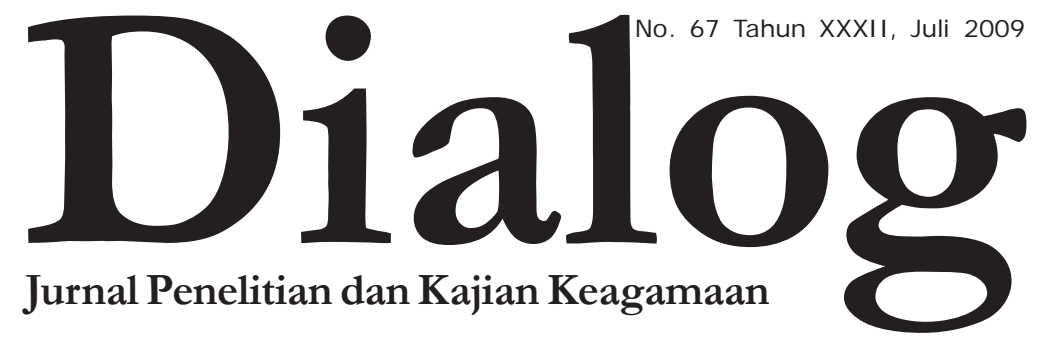

PERBANKAN SYARIAH DI INDONESIA

\begin{tabular}{|l|l|l|l|l|l|}
\hline Jurnal & $\begin{array}{l}\text { Nomor } \\
\text { Dialog }\end{array}$ & $\begin{array}{l}\text { Tahun } \\
\text { XXXII }\end{array}$ & $\begin{array}{l}\text { Halaman } \\
137\end{array}$ & Jakarta & ISSN \\
Juli 2009 & 0126-396X \\
\hline
\end{tabular}




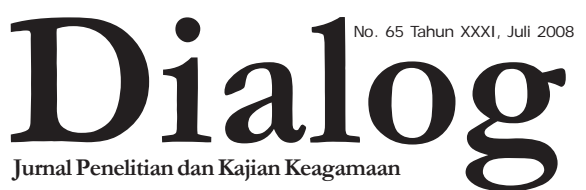

Pemi mpin Umum:

Prof. Dr. H. M. Atho Mudzhar, MA

Redaktur Aht :

Prof. Dr. H. Nasaruddin Umar, MA

Prof. Dr. H. Komarudin Hidayat, MA

Pemimpin Redaksi / Penanggung J awab

Drs. H. Syamsuddin

Waki l Pemi mpin Redaksi

H. Fanani Suprianto, SH., MM

Sekretaris Redaksi

M. Rosyid Fauzi, S.Si.

Dewan Redaksi

Prof. Dr. H. Abdurrahman Mas'ud

Drs. Amin Haedari

Prof. Dr. H. Maidir Harun

Drs. H. Mohammad Shohib, MA

Drs. H. Asmu'i, SH, MM

Chamdi Pamudji, SH., MM

Redaktur Eksekutif

M. Nasir, S.Th.I.

Redaktur Pelaksana

Moh. Rosyid Fauzi, S.Si

M. Nasir, S.Th.I

M. Adlin Sila, M.A

Abbas Jauhari, M.Ag

Admi ni strası

Drs. Dedy Curipno

Sutidjah

Desriyanti Nasution, S.IPI

Drs. H. Sahlani

Alamat Redaksi

Gedung Bayt Alquran Museum Istiqlal Komplek Taman Mini Indonesia Indah

Telp. (021) 87791444-87794982

Website:

www. balitbangdiklat.depag.go.id

Email:

info@depag.web.id

\section{PEIGITIR REDIKSL}

Karakteristik sistem perbankan syariah yang beroperasi berdasarkan prinsip bagi hasil memberikan alternatif sistem perbankan yang saling menguntungkan bagi masyarakat dan bank, serta menonjolkan aspek keadilan dalam bertransaksi, investasi yang beretika, mengedepankan nilai-nilai kebersamaan dan persaudaraan dalam berproduksi, dan menghindari kegiatan spekulatif dalam bertransaksi keuangan. Dengan menyediakan beragam produk serta layanan jasa perbankan yang beragam dengan skema keuangan yang lebih bervariatif, perbankan syariah menjadi alternatif sistem perbankan yang kredibel dan dapat dinikmati oleh seluruh

Jurnal Dialog diterbitkan oleh Badan Litbang dan Diklat Departemen Agama RI, sebagai media informasi dalam rangka mengembangkan penelitian dan kajiaan keagamaan di Indonesia. Dialog berisi tulisan ilmiah dan hasil penelitian dan pengembangan terkait dengan masalah keagamaan. Redaksi mengundang para peneliti agama, pengamat, cendekiawan, intelektual, dan akademisi untuk berdiskusi dan menulis secara bebas serta kreatif demi pengembangan penelitian maupun kajian keagamaan di Indonesia.

2 Dialog No. 67 Tahun XXXII, Juli 2009 
golongan masyarakat Indonesia tanpa terkecuali.

Fungsi Bank Syariah secara garis besar tidak berbeda dengan bank konvensional, yakni sebagai lembaga intermediasi (intermediary institution) yang mengerahkan dana dari masyarakat dan menyalurkan kembali dana-dana tersebut kepada masyarakat yang membutuhkannya dalam bentuk fasilitas pembiayaan. Perbedaan pokoknya terletak dalam jenis keuntungan yang diambil bank dari transaksi-transaksi yang dilakukannya. Bila bank konvensional mendasarkan keuntungannya dari pengambilan bunga, maka Bank Syariah dari apa yang disebut sebagai imbalan, baik berupa jasa (fee-base income) maupun mark-up atau profit margin, serta bagi hasil (loss and profit sharing).

Disamping dilibatkannya Hukum Islam dan pembebasan transaksi dari mekanisme bunga (interest free), posisi unik lainnya dari Bank Syariah dibandingkan dengan bank konvensional adalah diperbolehkannya Bank Syariah melakukan kegiatankegiatan usaha yang bersifat multifinance dan perdagangan (trading). Hal ini berkenaan dengan sifat dasar transaksi Bank Syariah yang merupakan investasi dan jual beli serta sangat beragamnya pelaksanaan pembiayaan yang dapat dilakukan Bank Syariah, seperti pembiayaan dengan prinsip murabahah (jual beli), ijarah (sewa) atau ijarah wa iqtina (sewa beli) (Farouk, 2009), dan lain-lain.
Dalam kajian Jurnal Dialog Edisi ini mencoba menyoroti perkembangan Perbankan Syariah di Indonesia yang beberapa tahun belakangan ini cukup mengalami perkembangan yang signifikan. Sehingga tidak sedikit bank konvensional yang membuka divisi syariah guna berebut nasabah yang kian meminati sistem perbankan syariah. Kajian Jurnal Dialog edisi ini diawali dengan tulisan Dr. Euis Amalia yang mengulas tentang Perbankan Syariah di Indonesia: Kontribusinya Bagi Perekonomian Nasional dan Peran Perguruan Tinggi dalam Rangka Akselerasi. Dilanjutkan dengan tulisan Muhammad Taufiki, M.Ag yang mengupas tentang Aplikasi Konsep Hilah dalam Pengembangan Produk Perbankan Syariah (Analisa terhadap Fatwa tentang Syariah Charge Card).

M. Adlin Sila, MA, peneliti di Badan Litbang dan Diklat Depag mencoba mengulas kemungkinan Bank Syariah Sebagai Bank Bagi Hasil? Ah. Azharuddin Lathif, M.Ag, MH, Dosen Fakultas Syariah dan Hukum UIN Jakarta menghadirkan tulisan tentang Analisis Yuridis Pengenaan Pajak Pertambahan Nilai (Ppn) Dalam Pembiayaan Murabahah di Perbankan Syariah. Sedangkan Prof. Dr. Abd. Rachman Mas'ud Kepala Puslitbang Kehidupan Keagamaan, melalui tulisannya mencoba menyoroti Etika Professional dan Ruh Agama di Awal Millenium. Yulizar D. Sanrego \& Aam S. Rusydiana dosen di Tazkia Institute 
menghadirkan tulisan tentang Peran Perbankan Syariah dalam Mendukung Umkm Pertanian. Kajian ini dilengkapi dengan tulisan Iyoh Masthiyah Peneliti Puslitbang Pendidikan Agama dan Keagamaan Badan Litbang dan Diklat Depag tentang Hak Milik dalam Islam Perspektif Ibn Taymiyah. Kajian dalam Jurnal Dialog edisi ini kian lengkap dengan hadirnya tulisan Yulianti Muhammad yang menganalisis Prospek Perbankan Syariah di Indonesia.

Di samping memuat artikel ilmiah, Jurnal Dialog edisi ini juga memuat laporan hasil penelitian oleh
Dr. Anwar Abbas tentang Ekonomi Islam dan Pemberdayaan Ekonomi Rakyat; Studi Kasus Pemberdayaan Melalui Koperasi Pondok Pesantren Sidogiri Kab. Pasuruan Jawa Timur. Kajian ini diakhiri dengan telaah buku yang mengulas buku karya Drs. Cik Basir, SH, MHI, 2009. Penyelesaian Sengketa Perbankan Syariah di Pengadilan Agama dan Mahkamah Syar'iyah. Semoga kajian yang dihadirkan Jurnal Dialog edisi ini memberikan manfaat yang berarti bagi para pembaca, khususnya dalam kajian Perbankan Syariah di Indonesia. Selamat Membaca!

Redaksi 


\section{DIPTIRISI}

\section{TOPIK}

PERBANKAN SYARIAH DI INDONESIA:

Kontribusinya Bagi Perekonomian Nasional dan

Peran Perguruan Tinggi dalam Rangka Akselerasi

Euis Amalia -6

APLIKASI KONSEP HILAH

DALAM PENGEMBANGAN PRODUK PERBANKAN SYARIAH

(Analisa terhadap Fatwa tentang Syariah Charge Card)

H. Muhammad Taufiki -20

BANK SYARIAH SEBAGAI BANK BAGI HASIL: MUNGKINKAH?

M. Adlin Sila -30

ANALISIS YURIDIS PENGENAAN

PAJAK PERTAMBAHAN NILAI (PPN)

DALAM PEMBIAYAAN

MURABAHAH DI PERBANKAN SYARIAH

Ah. Azharuddin Lathif -52

ETIKA PROFESSIONAL DAN RUH AGAMA

DI AWAL MILLENIUM

Abd. Rachman Mas'ud -69

PERAN PERBANKAN SYARIAH DALAM

MENDUKUNG UMKM PERTANIAN

Yulizar D. Sanrego \& Aam S. Rusydiana -74

HAK MILIK DALAM ISLAM PERSPEKTIF IBN TAYMIYAH

Iyoh Masthiyah --90

PROSPEK PERBANKAN SYARIAH

DI INDONESIA: CERAH ATAU BURAM?

Yulianti Muhammad --101

\section{PENELITIAN}

EKONOMI ISLAM DAN

PEMBERDAYAAN EKONOMI RAKYAT; Studi Kasus Pemberdayaan Melalui

Koperasi Pondok Pesantren Sidogiri Kab. Pasuruan Jawa Timur

Anwar Abbas -117

\section{BOOK REVIEW}

PENYELESAIAN SENGKETA PERBANKAN SYARIAH

(Di Pengadilan Agama dan Mahkamah Syariah)

R. Meilani Dewi - 132 


\title{
Bank Syariah Sebagai Bank Bagi Hasil: MUNGKINKAH?
}

\author{
OLEH : MUHAMMAD ADLIN SILA
}

\begin{abstract}
:
Islamic banking has the same purpose as conventional banking except that it operates in accordance with the rules of Syariah. The basic principle of Islamic banking is the sharing of profit and loss and the prohibition of riba (usury). Amongst the common Islamic concepts used in Islamic banking are profit sharing (Mudharabah), safekeeping (Wadiah), joint venture (Musharakah), cost plus (Murabahah), and leasing (Ijarah). Mudarabah is an arrangement or agreement between a capital provider (mudharib) and an entrepreneur, whereby the entrepreneur can mobilize funds for its business activity. Any profits made will be shared between the capital provider and the entrepreneur according to an agreed ratio, where both parties share in profits and only capital provider bears all the losses if occurred. While murabahah (Cost Plus) refers to the sale of goods at a price, which includes a profit margin agreed to by both parties. The bank is compensated for the time value of its money in the form of the profit margin. This is a fixed-income loan for the purchase of a real asset (such as real estate or a vehicle), with a fixed rate of interest determined by the profit margin. This article suggests that most of the Islamic banks have now given up or marginalized two risk-sharing/ profit-loss sharing (PLS) modes (Mudharabah and Musharakah), and have turned to the predominant mode of Murabahah, a mode that allows them to ensure that they avoid risk almost altogether in their transactions and earn relatively high return. Islamic banks have found Mudharabah and Musharakah to be inoperable in the modern context.
\end{abstract}

\section{Pendahuluan}

Bank syariah sedang menarik perhatian banyak orang. Ibarat gadis desa yang dahulunya kampungan dan dipandang sebelah mata kemudian berubah menjadi kosmopolit dan modernis sehingga menggoda orang kota untuk meliriknya. Saat ini, bank syariah atau bank Islam berkembang pesat di Indonesia. Salah satu pemain terbesar dalam lembaga keuangan syariah di Indonesia adalah Bank Muamalat Indonesia (BMI). Selain BMI, sekarang sudah ada 5 (lima) bank umum syariah (BUS) ditambah lagi ratusan unit layanan syariah di berbagai bank konvensional (Tabel 1). Perkembangan bank syariah ini adalah buah dukungan pemerintah Orde Baru pada saat itu yang ingin mengakomodir kaum Muslim santri berhaluan modernis dan untuk pemerataan 
ekonomi bagi kalangan Muslim. ${ }^{1}$ Jadi, selain politis, BMI hadir sebagai reaksi atas dominasi lembaga keuangan yang dimiliki etnis Cina ("Indeed, for some of its sopperters, the bank (BMI) has become as a symbol of opposition to Chinese economic dominance") (Hefner, 2003: 159). Sebelum berdirinya BMI, pada tanggal 15 Juli 1991, BPR Dana Mardhatillah (BPRDM) dan BPR Berkah Amal Sejahtera (BPRBAS) didirikan dan merupakan bank berskala kecil pertama yang beroperasi secara syariah. BPR syariah ini mulai beroperasi tanggal 19 Agustus 1991 di Bandung, Jawa Barat.

1 Robert W Hefner. 2003, “Islamizing Capitalism: On the Founding of Indonesia's First Islamic Bank." In Arskal Salim and Azyumardi Azra (eds), Shari'a and Politics in Modern Indonesia. ISEAS Series on Islam, 2003: 149-150. Pada umumnya, kaum Muslim kebanyakan berasal dari dua kubu: "modernis" yang menganut faham teologi yang ortodoks dan konsep-konsep moderen dan pendidikan modern; sementara kelompok "tradisional" adalah pengikut tokohtokoh agama kharismatik dan pondok pesantren (Ponpes). Organisasi sosial modernis, Muhammadiyah, memiliki cabang di seluruh Indonesia dan memiliki anggota sekitar 30 juta. Didirikan tahun 1912, Muhammadiyah mendirikan mesjid, klinik-klinik kesehatan, rumah Yatim Piatu, lembaga-lembaga santunan orang miskin, sekolah, perpustakaan umum dan universitas. Nahdlatul Ulama (NU), organisasi sosial terbesar kelompok tradisionalis fokus pada kegiatan yang sama dengan Muhammadiyah dan mendirikan kebanyakan sekolah Islam berasrama atau pesantren di Indonesia. Mengklaim anggota sebanyak 40 juta, NU adalah organisasi sosial terbesar di Indonesia dan bahkan di dunia. Didirikan tahun 1926, NU berada di seluruh Indonesia tetapi memiliki pengaruh terbesar di Jawa, dan sangat dipengaruhi oleh budaya Jawa (Hendro Prasetyo. NU dan Muhammadiyah: Civil Islam. Jakarta: PPIM-UIN Syarif Hidayatullah, 2000).
Di kalangan NU, yang mewadahi kaum abangan dan Muslim tradisional, bunga bank tidak sepenuhnya dianggap riba. Kebanyakan ulama NU tidak setuju kalau larangan Al-Qur'an (Al-Baqarah/2:275) tentang riba menyangkut semua jenis bunga bank. Sesuai dengan Kongres NU tahun 1938, NU menyimpulkan bahwa bunga bank halal selama membawa keuntungan bagi peminjam. Jadi, yang dianggap bunga bank itu riba adalah jenis bunga yang sangat merugikan (excessive interest). Meskipun sebagian kecil ulama NU tidak setuju dengan hasil Kongres ini. $^{2}$

NU mendirikan bank-bank skala kecil yang dinamai Bank Perkreditan (Pembiayaan) Rakyat (BPR). Untuk melakukan ini, NU bekerja sama dengan bank-bank swasta milik etnis Cina, seperti Bank Susila dan kemudian SUMMA (sebuah kelompok bank yang dimiliki oleh keluarga Soerjadjaja, konglomerat Cina di Indonesia). Jadi, BMI berdiri sebagai reaksi terhadap penguasaan bank swasta oleh kelompok Cina dan menerapkan prinsip nonbunga, sementara BPR NU menganggap bunga bank halal. Dan bahkan BPR NU bekerja sama dengan bank-bank swasta milik Cina. ${ }^{3}$ Saat itu sebenarnya, tidak sedikit ulama NU yang mengkritik kerjasama dengan bank-bank milik Cina ini. Kerjasama ini bubar dengan sendirinya oleh krisis moneter tahun 1997 yang mengakibatkan bangkrutnya bank-bank swasta tersebut. BPR NU

\footnotetext{
${ }^{2}$ Hefner, op.cit. 2003: 151-2.

3 Adlin Sila. "Ekonomi Islam dan Konsep Kesejahteraan Sosial (welfare state) di Indonesia: Sebuah Upaya Mencari Titik Temu". Dialog: Jurnal Penelitian dan Kajian Keagamaan, No.66 Tahun XXXI, Desember 2008.
} 
saat ini banyak yang kemudian berubah menjadi BPR syariah, sehingga tahun 2008 sudah terdapat 123 BPR Syariah di seluruh Indonesia (BI, 2007).

\section{SiKap Ormas Islam terhadap BUNGA BANK}

Hampir semua majelis fatwa ormas Islam yang berpengaruh di Indonesia, seperti Muhammadiyah dan Nahdlatul Ulama, telah membahas masalah bunga bank sebagai riba. Pembahasan itu sebagai bagian dari kepedulian ormas-ormas Islam tersebut terhadap berbagai masalah yang berkembang di tengah umatnya. Untuk itu, kedua organisasi tersebut memiliki lembaga ijtihad yaitu Majlis Tarjih Muhammadiyah dan Lajnah Bahsul Masa $;$ i il Nahdlatul Ulama. Majlis Tarjih Muhammadiyah telah mengambil keputusan mengenai hukum ekonomi/ keuangan di luar zakat, meliputi masalah perbankan (1968 dan 1972), keuangan secara umum (1976), dan koperasi simpan-pinjam (1989). Majlis Tarjih Sidoarjo (1968) memutuskan : 1). Riba hukumnya haram dengan nash sharih Al Qur'an dan As Sunnah. 2). Bank dengan sistem riba hukumnya haram dan bank tanpa riba hukumnya halal. 3). Bunga yang diberikan oleh bank-bank milik negara kepada para nasabahnya atau sebaliknya yang selama ini berlaku termasuk perkara musytabihat. Dan, 4). Menyarankan kepada PP Muhamma-diyah untuk mengusahakan terwujud-nya konsepsi sistem perekonomian, khususnya lembaga perbankan, yang sesuai dengan kaidah Islam.

Penjelasan keputusan ini menyebutkan bahwa bank negara, secara kepemilikan dan misi yang diemban sangat berbeda dengan bank swasta. Tingkat suku bunga bank pemerintah (pada saat itu) relatif lebih rendah dari suku bunga bank swasta nasional. Meskipun demikian, kebolehan bunga bank negara ini masih tergolong mutasyabihat (dianggap meragukan). Majlis Tarjih Wiradesa, Pekalongan (1972) : 1). Mengamanatkan kepada PP Muhammadiyah untuk segera dapat memenuhi keputusan Majlis Tarjih di Sidoarjo tahun 1968 tentang terwujudnya konsepsi sistem perekonomian, khususnya lembaga perbankan yang sesuai dengan kaidah Islam. 2). Mendesak Majlis Tarjih PP Muhammadiyah untuk dapat mengajukan konsepsi tersebut dalam muktamar yang akan datang. Masalah keuangan secara umum ditetapkan berdasarkan keputusan Muktamar Majlis Tarjih Garut (1976). Keputusan tersebut menyangkut bahasan pengertian uang atau harta, hak milik, dan kewajiban pemilik uang menurut Islam.

Sedangkan Lajnah Bahsul Masa'il Nahdhatul Ulama membagi status hukum bunga melalui beberapa kali sidang. Menurut Lajnah, hukum bank dan hukum bunganya sama seperti hukum gadai. Terdapat tiga pendapat ulama sehubungan dengan masalah ini : 1). Haram: sebab termasuk hutang yang dipungut rente, 2). Halal sebab tidak ada syarat pada waktu aqad, sementara adat yang berlaku, tidak dapat begitu saja dijadikan syarat, dan 3) Syubhat: (tidak tentu halalharamnya) sebab para ahli hukum berselisih pendapat tentangnya. Meskipun ada perbedaan pandangan, Lajnah memutuskan bahwa (pilihan) yang lebih berhati-hati ialah pendapat pertama, yakni menyebut bunga bank 
adalah haram. Keputusan Lajnah Bahsul Masa'il yang lebih lengkap tentang masalah bank ditetapkan pada sidang di Bandar Lampung (1982). ${ }^{4}$ Menindaklanjuti sikap orams-ormas Islam ini, Majelis Ulama Indonesia (MUI) pada tanggal 18-20 Agustus 1990 menyelenggarakan lokakarya bunga bank dan perbankan di Cisarua Bogor Jawa Barat. Hasil lokakarya tersebut dibahas lebih mendalam di Musyawarah Nasional IV MUI yang berlangsung di hotel Sahid Jaya Jakarta, 22 - 25 Agustus 1990. Berdasarkan amanat MUNAS IV MUI, dibentuk kelompok kerja untuk mendirikan Bank Islam di Indonesia. Pada 1 November 1991, berdirilah Bank Muamalat Indonesia (BMI) dan beroperasi sejak Mei 1992.

\section{Bank Syariah dan Misi Karikatifnya}

Setelah pendirian BMI ini, Bank Indonesia (BI) menyusun berbagai program untuk mensosialisasikan dan mengembangkan perbankan syariah, antara lain melalui pelatihan-pelatihan, seminar di berbagai kota dan penerbitan buku tentang perbankan syariah. Untuk membantu tugas ini, Bank Indonesia menunjuk PT. Tazkia Wahana Utama yang dipimpin oleh Muhammad Syafi'i Antonio (mantan Direktur BMI). Sebagai langkah awal, PT. Tazkia Wahana Utama ini merancang program-program pelatihan tentang penerapan ekonomi Islam baik dalam sektor keuangan maupun manajemen yang Islami serta berupaya untuk menjadi agen maupun jaringan

${ }^{4}$ Muhammad Syafi'i Antonio. Bank Syariah: Dari Teori ke Praktek. Cetakan kesepuluh (Cetakan ke-1, tahun 2004). Jakarta: Gema Insani dan Tazkia Cendekia, 2007: 63-65. lembaga-lembaga keuangan syariah seperti Asuransi Takaful dan BMI itu sendiri. ${ }^{5}$ Upaya ini mulai membuahkan hasil ketika PT Mayasari Bakti meminta Tazkia untuk memfasilitasi penyusunan perencanaan strategis Mayasari Group melalui sebuah lokakarya. Lokakarya yang diadakan di Hotel Horison Ancol ini dihadiri oleh seluruh pemegang saham (keluarga Bapak Haji Mahpud) dan jajaran direksi. Sedangkan Pemerintah Daerah Jawa Barat, meminta Tazkia untuk menyusun dan merintis pendirian Koperasi Syariah Berbasis BMT atau dikenal dengan Baitul Maal wat Tamwil (BMT).

Upaya Bank Indonesia bersamasama dengan PT. Tazkia Wahana Utama tersebut menggugah minat dari kalangan industri perbankan nasional untuk mendirikan Bank Syariah, baik dalam bentuk Unit Usaha Syariah maupun Bank Umum Syariah. Tidak lama berselang berdirilah Bank Syariah Mandiri (BSM) yang merupakan bank umum syariah pertama hasil konversi dari Bank Susila Bakti, kemudian Bank Mega mengakuisisi Bank Tugu dan mengkonversinya menjadi syariah dengan nama Bank Mega Syariah Indonesia (BSMI). Bank IFI merupakan bank umum pertama yang mendirikan

${ }^{5}$ Adlin Sila, "A Profile of Muhammad Syafi'i Antonio: A Leading Chinese Muslim in Syariah Economic Development," at the International Conference on Muslim Intellectuals as Agents of Change di Unversitas Islam Malang (Unisma), Batu Malang, 27-29 Nopember 2007, diselenggarakan oleh Training Indonesia's Young Leaders, Leiden University, Unisma Malang dan Dep. Agama RI, 2007: 3. (Versi Indonesianya terbit dengan judul "Porfil Muhammad Syafi'i Antonio: Tokoh Ekonomi Syariah di Indonesia", Jurnal Harmoni, No. 4, Tahun 2008).

Dialog No. 67 Tahun XXXII, Juli 2009 33 
Unit Usaha Syariah (UUS), lalu diikuti dengan pendirian UUS oleh bank-bank konvensional lainnya seperti: Bank JABAR, Bank Danamon, Bank Bukopin, Bank BNI, Bank BRI, Bank Niaga, Bank BII, Bank BTN, Bank Permata, dan lain-lain. ${ }^{6}$ Perkembangan dalam industri perbankan syariah ini diikuti pendirian lembaga keuangan syariah lain, baik dalam bentuk asuransi, pasar modal maupun pegadaian. Perusahaan asuransi syariah yang dimaksud antara lain: Asuransi Takaful, Asuransi Syariah Great Eastern, Asuransi Syariah AlMubarakah, Asuransi Syariah Alianz, Jasindo Takaful Syariah, Asuransi PaninLife Syariah, dan Prudential Syariah. Sementara dalam pasar modal dikenal Batasa Capital, Reksadana Syariah, PNM, dan HSBC Amanah.

Pada awal tahun 1998, setelah industri perbankan nasional dilanda krisis moneter (krismon), Bank Indonesia mulai intensif mengembangkan perbankan syariah dengan dikeluarkannya UU No. 10 Tahun 1998 dengan UU N0. 23 Tahun 1999 tentang Bank Indonesia dan UU No. 3 Tahun 2004, sebagai pengganti UU No. 7 tentang Perbankan. Undang-undang ini memberikan tempat bagi beroperasinya perbankan syariah di Indonesia yang sebelumnya memakai sistem bagi hasil (loss and profit sharing). Keberadaan perbankan syariah dipertegas lagi dengan diperbaharuinya UU No. 10 Tahun 1998 dengan UU N0. 23 Tahun 1999 tentang Bank Indonesia dan UU No. 3 Tahun 2004. Selanjutnya, pemerintah mengeluarkan lagi

6 Muhammad Adlin Sila, "A Profile of Muhammad Syafi'i Antonio:". Ibid.

34 Dialog No. 67 Tahun XXXII, Juli 2009
Peraturan Bank Indonesia (PBI) No. 9/ 19/PBI/2007 tanggal 17 Desember 2007 tentang Pelaksanaan Prinsip Syariah dalam kegiatan Penghimpunan Dana dan Penyaluran Dana serta Pelayanan Jasa Bank Syariah. Adapun rincian pelaksanaan PBI ini diatur dalam Surat Edaran (SE) Bank Indonesia. Dan puncaknya adalah terbitnya UU No. 21 Tahun 2008 tentang Perbankan Syariah. Kerangka hukum ini semakin menguatkan eksistensi perbankan syariah di Indonesia. Dalam kondisi perekonomian yang masih belum membaik ini, perbankan syariah dituntut kontribusinya sebagai penyedia pembiayaan alternatif bagi masyarakat Indonesia yang 16,58 persen atau sekitar 37,17 juta diantaranya masih dalam kategori miskin

Apakah terdapat hubungan antara penduduk miskin dengan kehadiran perbankan Syariah? Jawabannya ada. Peran BMI dalam pemberdayaan ekonomi rakyat dilakukan oleh Zainul Arifin (2000), mantan Direktur Utama BMI tahun 1996-1999. Dengan latar belakangnya ini, penulis sangat paham tentang berbagai program BMI dalam pemberdayaan ekonomi rakyat, misalnya melalui pola pembiayaan koperasi, usaha mikro, kecil dan menengah (UMK) melalui BPRS dan BMT. ${ }^{7}$ Pada saat pertama didirikan, BMI diharapkan dapat membiayai sektor usaha mikro dan kecil (UMK). Ketika itu dibentuk P.T. Manajemen Musyarakah Indonesia (MMI) oleh ICMI yang kemudian menjadi mediator antara BMI, investor dan pengusaha

7 Zainul Arifin. Memahami Bank Syariah: Lingkup, Peluang, Tantangan dan Prospek. Jakarta: Alvabet, 2000: 93-124.. 
UMK. Ide pendirian MMI ini muncul dari Sri Bintang Pamungkas, salah seorang intelektual Muslim dan Professor ekonomi dari Universitas Indonesia. Salah satu tujuan dari program ini adalah untuk memudahkan akses modal usaha bagi sebagian besar umat Islam pelaku UMK sehingga tercipta keadilan sosial.

Selain itu, peran aktor dalam hal ini praktisi lembaga keuangan syariah dalam melembagakan nilai-nilai Islam dalam sturktur keuangan syariah jarang dianalisis dalam studi sebelumnya. Para aktor ini melakukan rasionalisasi pemikiran keagamaan (ijtihad) dari sumber-sumber Islam klasik agar prinsip ekonomi Islam sesuai dengan konteks kekinian. Prinsipprinsip keuangan Islam diformulasikan ke dalam lembaga keuangan syariah baik yang berbentuk bank maupun LKMS dan sudah menjadi standar operation procedure (SOP). Upaya ini juga didukung oleh jaringan sosial (social network) antar organisasi-organisasi profesional keuangan syariah seperti, Tazkia Group yang membawahi PT. Tazkia Wahana Utama, Masyarakat Ekonomi Syariah (MES), Asosiasi Perbankan Islam Indonesia (ASBISINDO), Pusat Kajian Ekonomi Islam (PKES), Ikatan Cendikiawan Muslim Indonesia (ICMI), Dewan Syariah Nasional (DSN)-MUI, BMT Center Dompet Dhuafa, PINBUK, LAZNAS BMT dan lain sebagainya, terutama dalam melakukan sosialisasi perbankan syariah melalui seminar, lokakarya, penerjemahan dan penerbitan buku keuangan syariah.

Perbankan syariah memiliki karakteristik unik yaitu selain sebagai lembaga komersial yang mengejar keuntungan, lembaga ini juga berperan dalam mendukung sektor sosial. Pengelolaan dana sosial perbankan syariah, yang diperoleh dari zakat, infak, dan sedekah (ZIS) tahun 2007 lalu naik 46 persen, dari $\operatorname{Rp} 27,5$ miliar tahun 2006 menjadi Rp 40,1 miliar. ${ }^{8}$ Dana ini disalurkan dalam bentuk pinjaman usaha dan pinjaman kebajikan (Qardhul hasan). Kehadiran UU Perbankan Syariah No. 212008 dan sebelumnya juga disahkan UU Surat Berharga Syariah (SBSN) pada 10 April 2008 diharapkan dapat makin memacu peningkatan peran dan kontribusi perbankan syariah dalam mengentaskan kemiskinan, kesejahteraan masyarakat, serta pembukaan lapangan kerja melalui program sosial. Sedang dari sisi komersial, hadirnya UU Perbankan Syariah diharapkan makin memperkuat pijakan hukum perbankan syariah sehingga bisa setara dengan bank konvensional.

Tantangannya sekarang, sejauhmana pelaku perbankan syariah setelah memiliki payung hukum bisa mengakselerasi aktivitasnya dalam membangun perekonomian nasional. Lihatlah perkembangan perbankan syariah yang pesat saat ini dimana hingga tahun 2008 jumlah bank syariah mencapai 29 buah, terdiri dari lima Bank Umum Syariah (BUS) yaitu; Bank Muamalat Indonesia (BMI), Bank Syariah Mandiri (BSM), Bank Mega Syariah Indonesia (BMSI), Bank Rakyat Indonesia Syariah (BRIS), dan Bank Bukopin Syariah, dan 26 Unit Usaha Syariah (UUS) dari sejumlah bank nasional dan daerah. Ditinjau dari segi penyebarannya, jaringan kantor perbankan syariah tersebut kini telah

${ }^{8}$ Direktorat Perbankan Syariah, Bank Indonesia (BI), 2007. 
menjangkau masyarakat di 32 Provinsi di seluruh Indonesia. Meskipun kantor perbankan syariah (BUS, UUS dan BPRS) telah menjangkau 32 Provinsi. Namun sebagian besar dari jaringan kantor tersebut masih terkonsentrasi di Pulau Jawa (452 kantor atau 63, 6 persen) dan Pulau Sumatera (152 kantor atau 21,4 persen). Jika secara per Provinsi, penyebaran jaringan kantor perbankan syariah sebagian besar berada di wilayah Provinsi DKI Jakarta (206 kantor atau 29 persen) dan jumlah pembukaan layanan syariah tahun 2006 sebanyak 456.

Secara regional, pengembangan perbankan syariah masih didominasi di wilayah DKI Jakarta dengan pangsa pembiayaan maupun Dana Pihak Ketiga (DPK) masing-masing sebesar 46,4 persen dan 48,1 persen. Namun demikian, dari sisi pembiayaan pertumbuhan pembiayaan di wilayah DKI dan Wilayah Jawa lainnya mengalami penurunan, sebaliknya peningkatan terjadi di Wilayah

Tabel 1. Perkembangan Perbankan Syariah

(Sumber: Direktorat Perbankan Syariah, BI, 2007)

\begin{tabular}{|l|c|c|c|c|c|c|}
\hline Kelompok Bank & $\mathbf{2 0 0 3}$ & $\mathbf{2 0 0 4}$ & $\mathbf{2 0 0 5}$ & $\mathbf{2 0 0 6}$ & $\mathbf{2 0 0 7}$ & $\mathbf{2 0 0 8}$ \\
\hline Bank Umum Syariah (BUS) & 2 & 3 & 3 & 3 & 3 & 5 \\
Urit Usaha Syariah (UUS) & 8 & 15 & 19 & 20 & 26 & 26 \\
Bark Perkreditan Rakyat Syariah (BPRS) & 84 & 86 & 92 & 105 & 114 & 123 \\
Jumlah Kantor BUS \& UUS & 299 & 401 & 504 & 531 & 597 & 618 \\
Jumlah Layanan Syariah & - & - & - & 456 & 739 & 739 \\
\hline
\end{tabular}

Provinsi Jawa Barat (48 kantor atau 10,7 persen).

Dari data diatas terlihat bahwa pertumbuhan UUS lebih signifikan dibanding dengan BUS yang hanya berjumlah 5 (lima) hingga tahun 2008. Minimnya jumlah BUS ini terjadi karena disebabkan oleh biaya pendirian BUS yang relatif lebih mahal dibanding pendirian UUS, dan juga keberadaan Peraturan Bank Indonesia (PBI) No.9/ 7/PBI/2007 tanggal 4 Mei 2007 yang lebih menitikberatkan pada pembukaan layanan syariah di bank-bank konvensional. Dua hal ini yang membuat pertumbuhan jumlah BUS, UUS dan kantor cabang di bawah BUS dan UUS tidak mengalami peningkatan yang signifikan. Sedangkan, jumlah pembukaan layanan syariah pada tahun 2008 sejumlah 739, atau meningkat 62,1 persen dibandingkan
Kalimantan dan Sumatera Selain peningkatan pembiayaan, Wilayah Kalimantan juga memperlihatkan peningkatan penghimpunan DPK sehingga mempertegas pesatnya perkembangan perbankan syariah di wilayah tersebut selama 2007. Penyaluran pembiayaan oleh perbankan syariah menunjukkan peningkatan dibandingkan tahun sebelumnya. Ini tercermin dari laju pertumbuhannya sebesar 36,7 persen atau lebih tinggi dari pertumbuhan pada 2006 yaitu 34,2 persen. Berdasarkan kelompok bank, pertumbuhan yang tinggi ditunjukkan oleh Unit Usaha Syariah (UUS) bank umum konvensional yaitu sebesar 65,9 persen. Sementara pertumbuhan pembiayaan Bank Umum Syariah (BUS) relatif lebih rendah yaitu sebesar 29,8 persen. Namun pertumbuhan ini tidak mengurangi upaya mengoptimalkan 
penyaluran dana sebagaimana tercermin dari rasio pembiayaannya terhadap Dana Pihak Ketiga (DPK) sebesar 94,3 persen relatif setara dengan posisi 2006 sebesar 94,0 persen. Hingga saat ini, aset perbankan syariah sebesar Rp.52 triliun dengan pangsa pasar (market share) sekitar dua persen. Angka dua persen ini sesungguhnya masih jauh tertinggal dari aset bank konvensional yang mencapai Rp.1.700 triliun, meskipun bank syariah tumbuh 36 persen per tahun dan bank konvensional 19-20 persen (Lihat: Direktorat Perbankan Syariah, BI, 2008).

Berdasarkan jenis akad yang digunakan, pangsa kelompok pembiayaan berdasarkan qardhul hasan semakin meningkat menjadi 115,6 persen dengan laju pertumbuhan yang tinggi (tabel 2). Sementara pembiayaan berbasis jual beli (murabahah) yang meskipun tetap mendominasi portfolio pembiayaan namun, pangsanya mengalami penurunan dari 61,7 persen menjadi 59,2 persen.

Sejalan dengan membaiknya persepsi terhadap iklim investasi sebagaimana diindikasikan oleh Peningkatan Pembentukan Modal Tetap Bruto (PMTB) hingga sebesar 8,4 persen, alokasi pembiayaan perbankan syariah ke sektor-sektor produktif menunjukkan perkembangan yang menggembirakan. Pertumbuhan pembiayaan investasi tercatat sebesar 28,9 persen, melonjak dibandingkan pertumbuhan di 2006 yang hanya sebesar dua persen. Sedangkan pembiayaan modal kerja memperlihatkan pertumbuhan tertinggi yaitu sebesar 50,5 persen. Sebaliknya,

Tabel 2. Perkembangan Jenis-Jenis Pembiayaan Bank Syariah (Sumber: Direktorat Perbankan Syariah, BI, 2008)

\begin{tabular}{|l|c|c|}
\hline \multirow{2}{*}{ Jenis-Jenis Pembiayaan } & \multicolumn{2}{|c|}{ Pertumbuhan (\%) } \\
\cline { 2 - 3 } & $\mathbf{2 0 0 6}$ & $\mathbf{2 0 0 7}$ \\
\hline \multirow{3}{*}{ Musyarakah dan Mudharabah } & 31,5 & 35,73 \\
Piutang & 30.0 & 37.3 \\
Murabahah & 61,7 & 59,2 \\
Piutang Istishna & 19.6 & 4.2 \\
Qardhul hasan & 100.6 & 115.6 \\
Ijarah & 164.7 & 38.3 \\
Pembiayaan Modal Kerja & - & 50 \\
Pembiayaan Investasi & 2 & 28,9 \\
Konsumsi & 80,3 & 27,0 \\
\hline Total & 34.2 & 36.7 \\
\hline
\end{tabular}

berbasis bagi hasil yang terdiri atas pembiayaan mudharabah dan musyarakah mengalami peningkatan dari 31,5 persen menjadi 35,73 persen. Demikian pula halnya pembiayaan pertumbuhan pembiayaan konsumsi turun secara signifikan dari 80,3 persen pada 2006 menjadi 27,0 persen tahun 2008. 
Untuk memudahkan masyarakat dalam mengenali layanan perbankan syariah, Gubernur Bank Indonesia pada tanggal 2 Juli 2007 meresmikan penggunaan logo perbankan syariah Indonesia, yaitu iB (ai-bi) atau singkatan dari Islamic Banking (bank Islam). Sejak saat itu, seluruh bank syariah memasang logo tersebut pada seluruh tampilan visual produk dan jasa keuangan mereka.

Fenomena kehadiran bank-bank syariah seperti yang diuraikan diatas sangat menarik untuk dicermati, karena kita tahu bahwa sejak lama Indonesia dikenal telah menjadikan sistem kapitalisme sebagai ikon pembangunan nasional utamanya di zaman Orde Baru. Tapi, pada awal tahun 1990-an, pemerintah Indonesia membuka pintu bagi perkembangan perbankan syariah sebagai sistem perbankan alternatif dengan menerbitkan UU No. 7 Tahun 1992 hingga puncaknya ketika UU No.21 Tahun 2008 diterbitkan untuk memperkuat keberadaan perbankan syariah. Kehadiran UU menandai adanya konsep dualisme dalam sistem perbankan Indonesia: sistem konvensional (bunga) dan syariah (bagi hasil). Konsekuensi dari kerangka legalitas tersebut adalah pemerintah membentuk Direktorat Perbankan Syariah pada Bank Indonesia yang memiliki otoritas dalam merancang peraturan dan perundang-undangan perbankan syariah.

Umumnya, bank syariah seperti BMI, berpedoman pada konsep ekonomi syariah yang non-bunga (interest-free transaction). Bedanya dengan bank konvensional, bank syariah tidak mengenal sistem bunga. Bagi bank syariah, sistem bunga adalah riba. Hal

38 Dialog No. 67 Tahun XXXII, Juli 2009 ini berangkat dari prinsip ajaran Islam yang melarang mengambil riba (tambahan) dalam transaksi jual beli. Intinya, konsep ekonomi syariah melarang mengambil tambahan dari uang yang dipinjamkan, dan sebagai gantinya adalah sistem bagi hasil. Yang dibagi adalah untung-rugi yang diperoleh dari transaksi (loss-profit sharing): kalau transaksi untung, pihak bank dan peminjam berbagi, begitupun sebaliknya. $^{9}$

Pendek kata, ekonomi sebagaimana yang dikembangkan dan dipraktekkan oleh sistem ekonomi konvensional didasarkan pada pendekatan empirik sehingga terdesak untuk hanya tergantung pada nilai-nilai yang bersifat positif dan mengabaikan nilai normatif. Ekonomi syariah yang diterapkan oleh perbankan syariah mencoba untuk mengintegrasikan pertimbangan nilai moral agama (normative) kedalam pertimbangan rasional (positive) manusia dalam kegiatan ekonominya. Sebagaimana temuan Hefner (2003: 149) bahwa dengan adanya perubahan sosial (social change) dalam masyarakat di Indonesia seperti mobilitas sosial kaum santri modernis yang signifikan dalam ranah politik pada era Orde Baru dan peranan yang semakin nyata dari agama dalam kehidupan sosial ekonomi telah melanggengkan perkembangan ekonomi syariah di Indonesia. Dengan kata lain, nuansa politik sangat kental mewarnai masa awal berdirinya bank syariah.

Sementara itu, perkembangan perbankan syariah pada era reformasi

${ }^{9}$ M. Umer Chapra. The Future of Economics: An Islamic Perspective. Leicester, UK: The Islamic Foundations, 2000: 265. 
ini lebih dilandasi oleh kesadaran sosial keagamaan kaum Muslim yang semakin tinggi untuk mengintegrasikan agama dalam berbagai macam bentuk praktek ekonominya. Namun demikian, keberadaan Bank Umum Syariah (BUS) ini belum menjadi solusi yang optimal bagi pemberdayaan ekonomi para pelaku UMK. Memang BUS sudah menyalurkan bantuan kredit mikro bagi sejumlah UMK di beberapa daerah.

Tapi, upaya ini belum berujung pada pengentasan kemiskinan. BUS baru sebatas menyediakan layanan keuangan dan kredit yang bebas bunga bagi kaum Muslim. Sementara itu, kesulitan memperoleh kredit bagi pelaku UMK belum terselesaikan dengan keberadaan BUS, karena BUS masuk dalam kategori bank umum tapi berprinsip syariah yang juga menerapkan agunan (collateral) dan kehatihatian (prudentiality).

\section{Bank Syariah Sebagai Kajian Sosiologis}

Studi sosiologis lembaga keuangan syariah (LKS) di Indonesia masih diperlukan untuk melihat hubungan antara apa yang diidealkan atau diharapkan oleh ummat Islam terhada LKS dengan prakteknya di lapangan. Tahun 2009 ini, BMI telah berusia 17 tahun. Usia yang memasuki masa pubertas jika dianalogkan dengan manusia. BMI berkantor pusat di gedung Arthaloka, Jalan Jenderal Sudirman Jakarta Pusat. Kantor cabangya sudah tersebar di hampir seluruh propinsi di Indonesia. Karena tujuan dari didirikannya BMI adalah agar bank dapat menjangkau masyarakat Muslim lapisan bawah, maka dibangunlah lembaga-lembaga simpan pinjam yang disebut Baitul Maal wa Tamwil (BMT): Baitul Maal artinya rumah harta yang mengelola dana yang bersifat nirlaba (sosial), dan Tamwil adalah tempat mengelola dan menyalurkan dana masyarakat untuk tujuan profit.

Dalam mengemban amanah ini, BMI telah menyalurkan pembiayaan kepada: (1) kredit kepada Koperasi Primer untuk Anggotanya (KKPA), (2) Kredit Kepada Koperasi (KKop) dan (3) Kredit Usaha Tani (KUT). Sebagai upaya untuk memperluas jangkauan pelayanannya di daerah yang belum ada cabang BMI-nya, maka ditunjuklah beberapa BPRS sebagai channeling agent (atau wakil) BMI. BMI bersama ICMI, melalui peran Amir Radjab Batubara, memberikan banyak pelatihan dalam pendirian BPRS di pulau Jawa dan di luar pulau Jawa, seperti Sumatera Barat. Upaya ini banyak membantu perubahan (konversi) status Lumbung Pitih Nagari (LPN) yang sebelumnya berbadan hukum koperasi atau LKM informal menjadi BPRS. ${ }^{10}$

Hingga tahun 2000, BMI telah menyalurkan pembiayaan sejumlah Rp. 112,018 Milyar kepada 11.024 nasabah pengusaha kecil yang tersebar di DKI Jakarta, Jawa Barat, Yogyakarta, Jawa Tengah, Jawa Timur, Madura, Sulawesi Selatan, Kalimantan Timur dan beberapa daerah di Pulau Sumatera. Adapun sektor usaha yang dibiayai meliputi pertanian, pertambangan, perindustrian, konstruksi, perdagangan, transportasi, jasa dan lainnya. Penyaluran dana ini bersifat pember-

${ }^{10}$ Zainulbahar Noor. Bank Muamalat: Sebuah Mimpi, Harapan dan Kenyataan, Fenomena Kebangkitan Ekonomi Islam. Jakarta: Bening Publishing, 2006: 76. 
dayaan kelompok usaha mikro yang bergerak di sektor informal yang pada umumnya tidak bankable, terutama dari segi persyaratan formalnya. BMI juga mendapat kepercayaan mengelola dana International Development Fund (IDF) dari Kuwait sebesar Rp. 286 juta. Dana ini sudah disalurkan kepada 1.063 pedagang kaki lima (K-5), yang penyalurannya dilakukan melalui BPR Syariah di Yogyakarta dan NTB. ${ }^{11}$

Program Peningkatan kemandirian Ekonomi Rakyat bertujuan untuk menumbuhkembang-kan Unit Simpan Pinjam (USP) Koperasi Syariah. Program ini menyalurkan dana kepada 800 koperasi Syariah yang tersebar di 8 propinsi dengan jumlah plafon Rp. 8,2 Milyar, yang pada tahun 1999 meningkat menjadi 8,5 Milyar dengan sasaran 700 koperasi Syariah lainnya, sehingga tahun 2000 jumlah keseluruhan dana yang telah disalurkan kepada Koperasi Syariah berjumlah Rp. 16,7 Milyar. BMI sebagai bank alternatif dalam sistem perbankan Indonesia yang memakai sistem bagi hasil dan bukan bunga telah berupaya untuk mengutamakan sektor riil dalam aktivitas penyaluran dananya. Persoalan yang dihadapi sekarang adalah godaan untuk menyalurkan dana pembiayaan ke sektor ekonomi formal yang sudah mapan karena terkait dengan kompetisi dengan bank konvensional yang sudah berkembang jauh. Sementara misi awal BMI didirikan oleh para tokohnya adalah menjadi bank pemberdayaan ekonomi umat Islam yang sebagian besar pelaku usaha kecil menengah dan berada di sektor informal. Pendek kata, BMI pada awal berdirinya bertujuan untuk

\footnotetext{
${ }^{11}$ Zainal Arifin. Op.cit. 2000: 93.
}

memberdayakan ekonomi kerakyatan dengan mengembangkan BMT. ${ }^{12}$

Selain mengutamakan prinsip syariah atau tanpa bunga (interest-free transactions) dalam transaksi keuangannya, BMI juga memberikan andil dalam pengentasan kemiskinan (poverty alleviation). Tantangannya adalah, di tengah ambisi perbankan syariah untuk mencapai market share sebesar 5 persen dari aset perbankan nasional akhir tahun 2008, maka diasumsikan bahwa praktek bank syariah akan banyak mengadopsi praktek bank konvensional umumnya. Misalnya, bank syariah akan lebih berorientasi pada keuntungan (profit oriented), dan kurang peduli terhadap pemberdayaan ekonomi rakyat kecil. Kesan awal sudah membuktikan gejala tersebut yaitu dengan sistem penyaluran kredit bank syariah yang hampir mirip dengan bank konvensional yaitu pemberlakuan prinsip kehati-hatian (prudentiality) dan agunan (collateral) bagi nasabah. Skema pembiayaan mudharabah dan musyarakah (bagi hasil) dimana bank syariah akan menanggung kerugian jika usaha yang dibiayai merugi semakin menurun prosentasenya (lihat Tabel.2).

Padahal kedua skema pembiayaan inilah yang paling tepat untuk membantu sektor UMK. Skema ini semakin ditinggalkan oleh bank syariah karena mudahnya terjadi kemacetan (default) atau wanprestasi dan keuntungan yang diperoleh sedikit. Di Malaysia, skema mudharabah diplesetkan menjadi "mudah rebah", artinya skema mudharabah sering menimbulkan kemacetan yang tinggi sehingga mudah merebahkan bank syariah

${ }^{12}$ Zainal Arifin. Ibid. 2000: 93-124. 
(bangkrut). ${ }^{13}$ Lahirnya bank syariah di Indonesia memang mengikuti perkembangan bank Islam di Malaysia. Harus diakui bahwa Malaysia menjadi perintis dan pemain utama di kawasan Asia Tenggara dalam jasa perbankan yang beroperasi sesuai syariat Islam ini. Para pendiri bank syariah pertama (baca: BMI) banyak belajar dari perkembangan bank syariah di Malysia. Jadi tidak salah kalau perkembangan yang terjadi di Malaysia menjadi referensi bagi Indonesia untuk mengembangkan bank syariahnya.

Meskipun begitu, dibandingkan bank konvensional, porsi pembiayaan bank syariah pada sektor UMK cukup besar yaitu 71,01 persen dibanding bank konvensional yang hanya 48,34 persen. ${ }^{14}$ Pemerintah Indonesia sejak dulu telah mengembangkan lembagalembaga keuangan dan kredit mikro dan beberapa di antaranya masih tetap bertahan dan berkembang. BMT, baik yang didukung oleh bank Syariah maupun tidak, memperoleh dukungan dari pemerintah Indonesia secara luas. Misalnya, Kementrian Koperasi dan Usaha Kecil Menengah (KUMK) memiliki beragam kebijakan yang mendukung jenis dan bentuk lembaga keuangan mikro (LKM), selain koperasi yang sudah lama dikenal maupun LKM Syariah atau LKMS dalam bentuk Baitul Maal wat Tamwil (BMT) yang relatif baru. Kehadiran BMT sebagai bagian dari program pemberdayaan ekonomi rakyat yang dicanangkan oleh pemerintah, selain menjadi lembaga keuangan alternatif selain perbankan syariah juga menambah kesemarakan perkembangan ekonomi mikro di

${ }^{13}$ Zainulbahar Noor, 2006, op.cit, h.78.

${ }^{14}$ Direktorat Perbankan Syariah, BI, 2008.
Indonesia dalam mendorong pemberdayaan ekonomi rakyat. Bagi para tokoh pendiri awal LKS, BMT yang sekarang berjumlah lebih 3000-an hadir sebagai reaksi kegagalan bank syariah dalam mengimplementasikan konsep keuangan syariah yang betul-betul bisa mengentaskan kemiskinan akut yang dialami sebagian besar umat Islam. ${ }^{15}$

Indikasi terhadap gejala ini sudah dipelajari oleh Richards (2003: 161-200) yang mengambil kasus Bank Islam Malaysia Berhard (BIMB). Richards menemukan bahwa konsep bank syariah yang mengedepankan moralitas kadang berbeda antara konsep (ide) dengan skema dan produk yang riil ditawarkan oleh BIMB kepada nasabahnya. Ada yang betul-betul islami, dan ada yang masih sama dengan sistem konvensional. Temuan ini mengindikasikan bahwa untuk benar-benar menciptakan konsep yang islami maka antara konsep syariah dan produk syariah yang dihasilkan harus selaras. Selanjutnya, M. Umer Chapra (2000a: 21-37) mempertanyakan bahwa apakah umat Islam memang membutuhkan ekonomi Islam. Chapra menyalahkan lambatnya perkembangan sistem ekonomi syariah di banyak negara Muslim, karena kurang didukung oleh pemerintah dan masyarakatnya, sementara lembaga

${ }^{15}$ Studi yang secara independen tentang BMT dan secara khusus menggambarkan peran BMT, sebagai lembaga keuangan mikro syariah dilakukan oleh Awalil Rizky (2007). Rizky secara normatif menggambarkan kelebihan-kelebihan BMT dibandingkan dengan lembaga konvensional dalam upaya pemberdayaan ekonomi rakyat (Awalil Rizky. Optimalisasi Keunggulan BMT Bagi Pengembangan Ekonomi Rakyat; dan BMT: Fakta dan Prospek. Yogyakarta: UCY Press, 2007).

Dialog No. 67 Tahun XXXII, Juli 2009 
keuangan konvensional sudah sangat maju.

Yang menarik juga adalah studi yang dilakukan oleh Mohamed Aslam Haneef tahun (2005), seorang pengkaji bank Islam di Malaysia juga. Haneef berkeyakinan bahwa sebenarnya metode ilmiah dalam memahami ekonomi tidak tunggal tapi jamak atau pluralistik. Dari segi epistemologi, ekonomi Islam menawarkan konsep bahwa masalah ekonomi manusia dapat didasarkan pada nilai, norma, hukum dan lembaga yang bisa saja berasal dari berbagai sumber pengetahuan termasuk Islam. Dari itu, model dan teori bisa dibangun dengan misalnya menyusun asumsi-asumsi, variabel-variabel dan hubungan-hubungannya, menyusun prinsip, hukum, asumsi, hipotesis yang dapat diuji validitasnya. Yang penting, katanya, agama jangan lagi dilihat sebagai sesuatu yang terbelakang. Studi lain adalah yang dilakukan Miriam Sophia Netzer (2004). Netzer menganalisis tentang riba, atau konsep bunga dalam hukum Islam (fikih) dan peranannya dalam wacana hukum dan negara.

Studi yang dilakukan oleh Robert W Hefner (2003) cukup menarik. Hefner yang menggunakan pendekatan antropologis menemukan bahwa pendirian BMI adalah salah bentuk dari upaya untuk meng-Islam-kan sistem kapitalisme di Indonesia (islamizing capitalism). Poin penting dari Hefner ini juga didasari oleh studi perbandingannya dengan perkembangan bank Islam di Malaysia. Di Malaysia, perkembangan bank Islam identik dengan dua hal: ke-Islam-an dan ke-Melayu-an. Islam dan Melayu tidak terpisahkan, sehingga fanatisme agama dan kesukuan bercampur aduk. Sedangkan di Indonesia tidaklah demikian adanya. Kehadiran bank syariah di Indonesia awalnya dianggap sebagai kelanjutan perjuangan negara Islam (Darul Islam) di zaman Orde Lama, sehingga murni dianggap sebagai fanatisme agama belaka. Di era reformasi ini, kehadiran bank syariah selalu diarahkan kepada bagaimana lembaga ini bisa menjadi oase dari kondisi kemiskinan umat yang akut.

Perkembangan lembaga keuangan syariah secara keseluruhan pasca Orde Baru tidak selalu dilandasi oleh alasan politis sebagaimana kesimpulan Robert W. Hefner tahun 1990-an lalu. Tentunya, aspek sosial yang meliputi dimensi institusionalisasi ikut berperan dalam menunjang perkembangan kelembagaan lembaga keuangan syariah seperti bank syariah dan LKMS seperti; BPR syariah, koperasi syariah dan BMT saat ini. Jika awalnya BMI, misalnya, lahir karena alasan politis, maka BMI dan lembaga keuangan syariah lainnya sekarang tumbuh pesat karena secara sosial-kultural masyarakat sudah mengenali manfaat dari jasa keuangan syariah yang menggunakan konsep bagi hasil ini. Temuan ini telah membantah tesis lama yang mengatakan bahwa fanatisme agama menjadi faktor perkembangan bank syariah.

\section{Teknologi Keuangan Bank Syariah}

Ekonomi Islam mengajarkan prinsip kesejahteraan sejati dimana kemapanan materi harus seimbang dengan kemapanan moral. Keseimbangan dalam spiritualitas bahwa pada harta terdapat hak individu, hak Tuhan dan hak sesama, karena Islam mengakui hak milik 
pribadi secara terbatas. Pemenuhan kepentingan pribadi dan memaksimalkan harta dan konsumsi harus diganti dengan usaha untuk memenuhi kepentingan sosial dan mengoptimalkan kesejahteraan umat manusia. Untuk mewujudkan prinsip ekonomi Islam ini maka transaksi keuangan yang berdasarkan bunga ditolak, karena tidak mengandung prinsip keseimbangan dan kesejahteraan bersama. Sebaliknya, ekonomi Islam menerapkan transaksi keuangan non-bunga (interestfree transaction) dalam lembaga keuangan, karena Islam melarang untuk mengambil kelebihan (riba) dari pokok uang yang dipinjamkan. Sebagai pengganti bunga, lembaga keuangan Islam membolehkan sistem bagi hasil. Yang dibagi adalah keuntungan dan kerugian yang diperoleh dari usaha yang dijalankan peminjam. Konsep dasar Islam adalah tidak ada yang bisa menentukan untung dan rugi seseorang di kemudian hari. Karena bisnis itu berisiko maka yang dibagi bukan hanya keuntungan, tapi juga kerugian. Jadi, Islam melarang untuk menentukan keuntungan di awal transaksi. ${ }^{16}$

Dalam bukunya, Syafi'i (2007) mendefinisikan riba secara bahasa yang bermakna: ziyadah (tambahan). Dalam pengertian lain, secara linguistik riba juga berarti tumbuh dan membesar. Sedangkan menurut istilah teknis, riba berarti pengambilan tambahan dari harta pokok atau modal secara batil. Menurut Syafi'i, terdapat beberapa pendapat dalam menjelaskan riba. Tapi, secara umum terdapat benang merah yang menegaskan bahwa riba adalah pengambilan tambahan, baik dalam transaksi jual-beli maupun pinjammeminjam secara tidak sah (bathil) atau bertentangan dengan prinsip transaksi ekonomi (muamalat) dalam Islam. Syafi'i membedakan antara investasi dengan membungakan uang. Investasi adalah kegiatan usaha yang mengandung risiko karena berhadapan dengan unsur ketidakpastian. Dengan demikian, perolehan pengembaliannya tidak pasti dan tidak tetap. Islam mendorong masyarakat ke arah usaha nyata dan produktif. Islam mendorong seluruh masyarakat untuk melakukan investasi dan melarang membungakan uang. Sesuai dengan definisi di atas, menyimpan uang di bank syariah termasuk kategori kegiatan investasi karena perolehan kembaliannya dari waktu ke waktu tidak pasti dan tidak tetap. Besar kecilnya perolehan kembali itu tergantung kepada hasil usaha yang benar-benar terjadi dan dilakukan bank sebagai pengelola dana. Bank syariah tidak sekadar menyalurkan uang, tapi juga berupaya meningkatkan pengembaliannya, sehingga lebih menarik dan lebih memberi kepercayaan bagi pemilik dana.

Tabel 3. Perbedaan Sistem Bunga dengan Bagi Hasil ${ }^{17}$

\begin{tabular}{|c|l|l|}
\hline No. & \multicolumn{1}{|c|}{ Bunga } & \multicolumn{1}{|c|}{ Bagi Hasil } \\
\hline 1. & $\begin{array}{l}\text { Penentuan bunga dibuat pada waktu } \\
\text { akad dengan asumsi harus selalu } \\
\text { untung }\end{array}$ & $\begin{array}{l}\text { Penentuan besarnya rasio/ nisbah bagi hasil } \\
\text { dibuat pada waktu akad dengan berpedoman } \\
\text { pada kemungkinan untung rugi. }\end{array}$ \\
\hline
\end{tabular}

${ }^{16}$ Taqyuddin An-Nabbani. Membangun Sistem Ekonomi Alternatif: Perspektif Islam. Surabaya: Risalah Gusti, cetakan ketujuh, 2002: 50.

${ }^{17}$ Syafi'i, op.cit. 2007: 61. 


\begin{tabular}{|c|l|l|}
\hline 2. & $\begin{array}{l}\text { Besarnya persentase berdasarkan pada } \\
\text { jumlah uang (modal) yang dipinjamkan }\end{array}$ & $\begin{array}{l}\text { Besarnya rasio bagi hasil berdasarkan pada } \\
\text { jumlah keuntungan yang diperoleh. }\end{array}$ \\
\hline 3. & $\begin{array}{l}\text { Pembayaran bunga tetap seperti yang } \\
\text { dijanjikan tanpa pertimbangan apakah } \\
\text { proyek yang dijalankan oleh pihak } \\
\text { nasabah untung atau rugi }\end{array}$ & $\begin{array}{l}\text { Bagi hasil tergantung pada keuntungan } \\
\text { proyek yang dijalankan. Bila usaha merugi, } \\
\text { kerugian akan ditanggung bersama oleh } \\
\text { kedua belah pihak. }\end{array}$ \\
\hline 4. & $\begin{array}{l}\text { Jumlah pembayaran bunga tidak } \\
\text { meningkat sekalipun jumlah } \\
\text { keuntungan berlipat atau keadaan } \\
\text { ekonomi sedang 'booming". }\end{array}$ & $\begin{array}{l}\text { Jumlah pembagian laba meningkat sesuai } \\
\text { dengan peningkatan jumlah pendapatan }\end{array}$ \\
\hline 5. & $\begin{array}{l}\text { Eksistensi bunga diragukan (kalau } \\
\text { tidak dikecam) oleh semua agama } \\
\text { termasuk Islam }\end{array}$ & $\begin{array}{l}\text { Tidak ada yang meragukan keabsahan bagi } \\
\text { hasil. }\end{array}$ \\
\hline
\end{tabular}

Secara umum, bank syariah tidak berbeda dengan BPR syariah begitupun BMT, yakni menggunakan 3 prinsip: (1). Prinsip bagi hasil. Dengan prinsip ini ada pembagian hasil antara bank syariah dengan penerima pinjaman atau penabung. Prinsip ini terdiri dari: Mudharabah, Musyarakah, Muzara'ah, dan Musyaqah.
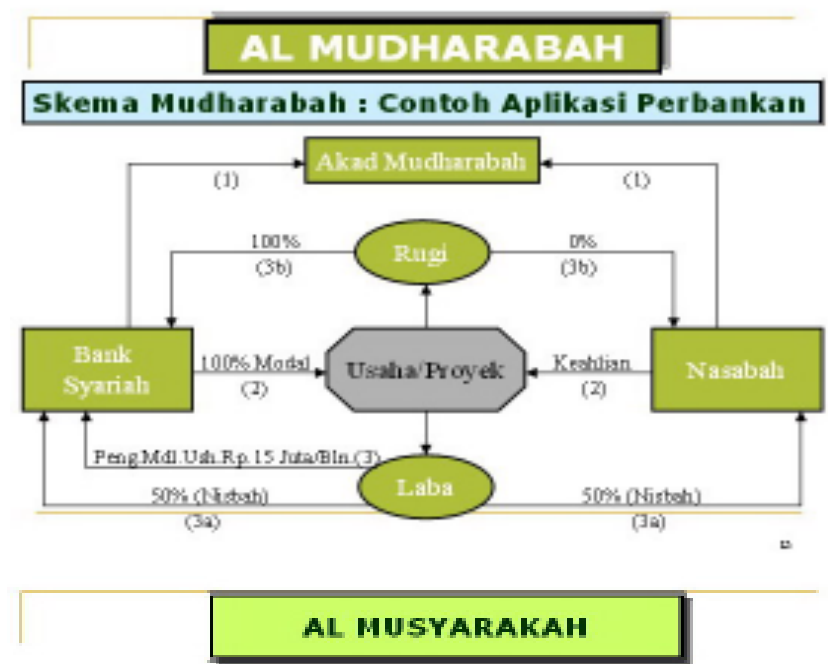

Skema Musyarakah :

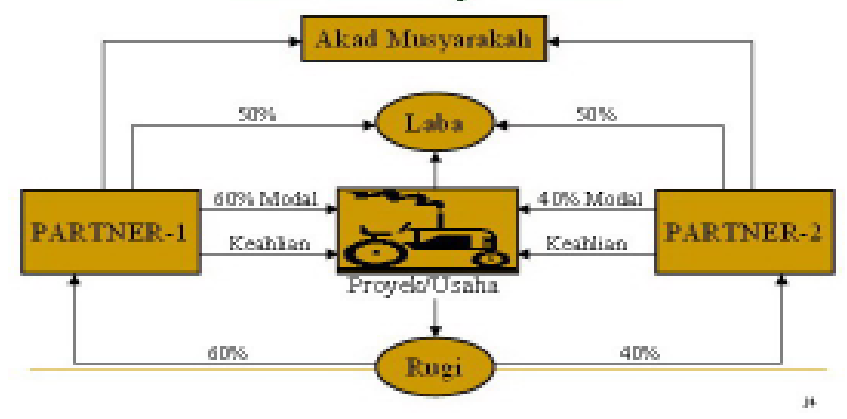

44 Dialog No. 67 Tahun XXXII, Juli 2009 
(2). Sistem Jual Beli. Sistem ini merupakan suatu tata cara jual beli yang dalam pelaksanaannya bank syariah mengangkat nasabah sebagai agen yang diberi kuasa melakukan pembelian barang. Bank kemudian menjual kembali (resell) barang tersebut kepada nasabah dengan ditambah (cost plus). Sistem jual beli ini terdiri dari; Bai' al - Murrabahah, Bai' as - Salam, Bai' al - Istishna, Bai' Bitsaman Ajil. adanya hubungan antara etika Protestan, utamanya sekte Calvinis, dengan semangat Kapitalisme. Sedangkan Nelson (2001) mengatakan bahwa; "economist today are being pushed to accept that they may have to take up the role of religion if they want to understand the full workings of economic systems". ${ }^{18}$ Artinya, para ekonom saat ini dianjurkan untuk mendalami agamanya agar lebih memahami

\section{AL MURABAHAH}

Skema Murabahah :

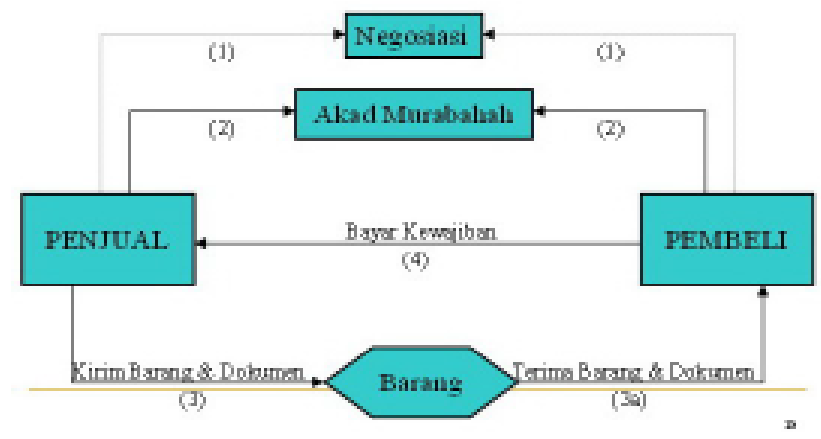

Dan prinsip yang terakhir, (3). Sistem non - Profit, yaitu; Qordhul Hasan. Sistem yang sering disebut pembiayan kebajikan ini merupakan pembiayaan yang bersifat sosial dan non-komersial atau nirlaba. Nasabah cukup mengembalikan pokok pinjamannya saja.

\section{Peranan Agama dalam Praktek EKONOMI}

Fenomena keuangan syariah belakangan ini memperkaya diskusi tentang pengaruh agama dalam praktek ekonomi. Pengaruh agama lain seperti Kristen Protestan dalam tindakan ekonomi sudah beberapa studi membuktikannya. Yang pertama dan utama adalah Max Weber yang melihat keseluruhan sistem kerja ekonomi. Pandangan yang lain, misalnya, Don Lovoie dan Emily Chamlee-Wright menemukan bahwa praktek agama memberikan kontribusi pada peningkatan kinerja ekonomi. ${ }^{19}$

Perlu digarisbawahi bahwa belakangan tesis Weber tentang hubungan antara nilai Calvinis dengan semangat Kapitalisme dikritik banyak orang. Ada yang menyebutnya tidak bersifat kausalitas, tapi lebih affinitas

18 Robert Nelson. Economics As Religion. University Park PA, The Pennsylvania State University Press, 2001: 206.

${ }^{19}$ Don Lovoie dan Emily Chamlee-Wright. Culture and Enterprise: the Development, Representation and Morality of Business, Routledge, London, 2000: 10.

Dialog No. 67 Tahun XXXII, Juli 2009 
atau bersifat sejajar (elective affinities). Dan, ini yang lebih penting, tidak semua nilai-nilai Calvinis memberikan sumbangan pada Kapitalisme, tapi hanya sebagian. Misalnya, nilai asketis (asceticism) yang berarti pantang terhadap kenikmatan-kenikmatan duniawi (disenchanment of the world), kerja keras dan berhemat. ${ }^{20}$ Inti ajaran Calvinis terletak pada konsep beruf (calling) atau vocation yang berarti panggilan, dan semua penganut Calvinis yakin sebagai yang terpanggil. Tugas di dunia adalah memenuhi panggilan Tuhan sehingga menuntut kerja keras untuk memperoleh kebahagiaan di dunia. Kebahagiaan di dunia akan menentukan keselamatan di hari kemudian (inner worldly). ${ }^{21}$ Banyak sekali sosiolog yang melakukan interpretasi yang berbeda terhadap tesis etika Protestan Weber. Ada yang menganggap terdapat hubungan kausalitas antara etika Protestan dengan Kapitalisme, seperti Robert, N. Bellah dalam Beyond Belief-nya. Tapi ada juga yang menolaknya seperti Michael Hill (1973). ${ }^{22}$ Perbedaan ini timbul karena adanya salah pengertian mengenai sosiologi Weber atau karena sosiologi Weber sendiri mengandung berbagai tesis yang tidak selamanya konsisten. Dan, parahnya, kebanyakan sosiolog

${ }^{20}$ Ignas Kleden. "Kapitalisme, Spiritualitas Keagamaan dan Etos Kerja: Mengenang 100 tahun The Protetstant Ethic and The Spirit of Capitalism Max Weber". (tidak diterbitkan), Seminar Nasional "Membangun Etos Bangsa", Jakarta, 4 Desember 2005: 4.

${ }^{21}$ Max Weber. The Protestant Ethic and the Spirit of Capitalism. London and New York: Routledge Calssics, 2002: 53.

${ }^{22}$ Michael Hill. A sociology of Religion. London: Heinemann Educational, 1973. belakangan cenderung menganggap seorang ahli sosiologi yang sudah masyhur selalu konsisten. ${ }^{23}$

Weber (1978) menegaskan bahwa semakin modern masyarakat, maka perilaku individu di dalamnya semakin rasional. Peran agama digantikan oleh lembaga-lembaga modern yang berfungsi untuk menjaga kohesi sosial. Di tempat lain, Weber mengatakan pula; The church did influence people's attitudes toward the economy but mostly in a negative manner because the economic mentality it furthered was essentially traditionalistic. The church like hierocracy more generally has casually encouraged "a non-capitalistic and partly anti-capitalistic" (mentality). ${ }^{24} \mathrm{Di}$ tempat lain, menurut Weber (1978), semakin modern masyarakat maka akan semakin rasional dalam melakukan tindakan sosial (rational choice). Jadi, awalnya memang agama dalam hal ini etika Protestan sekte Calvinis menjadi inspirasi dalam membentuk semangat Kapitalisme dalam kegiatan ekonomi, namun belakangan konsep-konsep itu di-pahami secara sekuler. Etika Protestan tidak bisa dijadikan faktor determinan timbulnya kemajuan Kapitalisme di Barat, karena tanpa itu pun Kapitalisme akan berkembang dengan sendirinya seperti yang dicapai saat ini. Kasus kapitalisasi dan industrialisasi yang sukses di Jepang, Korea Selatan dan China yang didorong oleh ajaran Konfusianisme bisa menjadi pengecuali-an dalam hal ini.

\footnotetext{
${ }^{23}$ Bryan S Turner. Weber and Islam: A Critical Inquary. London, Henley and Boston, 1974: 113.

${ }^{24}$ Richard Swedberg (eds) Richard Swedberg (eds), (2005). Handbook of Economic Sociology. Russel Sage Foundation: Princeton University Press.. Handbook of Economic Sociology. Russel Sage Foundation: Princeton University Press. 2005: 112.
} 
Sistem ekonomi dunia sangat dipengaruhi oleh Adam Smith melalui bukunya An Inquiry into the Nature and Causes of the Wealth of Nations yang ditulis pada tahun 1776. Isi buku tersebut sarat dengan pemikiran-pemikiran tingkah laku ekonomi masyarakat. Dari dasar filosofi tersebut kemudian menjadi sistem ekonomi, dan pada akhirnya kemudian mengakar menjadi ideologi yang mencerminkan suatu gaya hidup (way of life). Meskipun karya-karyanya terdahulu lebih bernuansa moral (the moral sentiment), Smith berpendapat bahwa motif manusia melakukan kegiatan ekonomi adalah atas dasar dorongan kepentingan pribadi (selfinterest), yang bertindak sebagai tenaga pendorong yang membimbing manusia mengerjakan apa saja asal masyarakat sedia membayar. Smith mengatakan tentang ini sebagai berikut;

"Bukan berkat kemurahan tukang daging, tukang pembuat bir, atau tukang pembuat roti kita dapat makan siang, akan tetapi karena mereka memperhatikan kepentingan pribadi mereka. Kita berbicara bukan kepada rasa perikemanusiaan mereka, melainkan kepada cinta mereka kepada diri mereka sendiri, dan janganlah sekalikali berbicara tentang keperluan-keperluan kita, melainkan tentang keuntungankeuntungan mereka". ${ }^{25}$

Motif kepentingan individu yang didorong oleh filsafat liberalisme ini kemudian yang melahirkan sistem

${ }^{25}$ Robert L Heilbroner. 1986. The Nature and Logic of Capitalism. W W Norton \& Co Inc; Revised edition, 1986. ekonomi pasar bebas pada akhirnya melahirkan ekonomi Kapitalis di setiap belahan dunia termasuk Indonesia. Konsepnya yang terkenal adalah laissez faire, yang berarti tiadanya intervensi pemerintah, sehingga terciptalah individualisme ekonomi dan kebebasan ekonomi (self-interests and free will). Ujung dari semua ini adalah terciptanya homo economicus. Para praktisi ekonomi syariah mengkritik konsep ekonomi Indonesia yang dipengaruhi oleh pengalaman sejarah Eropa Barat sejak abad ke-17. Apa yang ditampilkan oleh beberapa penulis tentang ekonomi sangat bernuansa pengalaman Eropah yang mungkin saja tidak berlaku universal. Dalam Islam, terdapat anjuran untuk mengejar kepentingan duniawi demi bekal di akhirat nanti (Mohamed Aslam Haneef, 2005).

Selama ini, ekonomi dipahami sebagai ilmu empirik yang tergantung pada nilai-nilai yang bersifat positif dan mengabaikan nilai normatif. Padahal, ilmu ekonomi merupakan ilmu yang paling bergantung pada nilai dan paling normatif diantara ilmu-ilmu sosial lainnya. Model dan teorinya akan selalu didasarkan pada sistem nilai tertentu, yaitu pada pandangan tentang hakikat manusia (epistemologis dan ontologis). Konsep ekonomi moderen dipengaruhi oleh pengalaman sekularisme terutama Eropah Barat. Sementara itu, pengaruh agama, dan sistem nilai budaya yang masih berlaku dan semakin nyata dalam kehidupan ekonomi di Amerika Latin, Asia dan Afrika telah meruntuhkan paradigma positivisme yang telah digunakan oleh para sarjana ekonomi klasik. Konsep tentang ekonomi berdasarkan agama (religious based economics) mungkin akan

Dialog No. 67 Tahun XXXII, Juli 2009 
lebih difahami oleh sarjana Barat sebagai ekonomi yang berdasarkan etika (ethical economics), atau ekonomi yang moralis (Marion Fourede/Kieran Hearly, 2007: 285-311; dan Amitai Etzioni, 1988). Dalam Islam, manusia dianjurkan untuk mengelola sumber daya alam di dunia ini bukan hanya untuk sukses di dunia ini tapi juga di hari kemudian (akhirat). Islam mengajarkan untuk menyeimbangkan antara kepentingan duniawi dan ukhrawi, badan dan jiwa, keimanan dan akhlak mulia, pengetahuan dan perbuatan baik, sehingga akan tercipta homo islamicus yang bermoral. ${ }^{26}$

\section{Mungkinkah Bagi Hasil Dilaksanakan SEPENUHNYA?}

Dari data di lapangan, tidak sedikit masyarakat umum dan bahkan kalangan intelektual terdidik, yang belum memahami secara komprehensif konsep bagi hasil pada Lembaga Keuangan Syariah (LKS), apakah itu bank syariah, BPR Syariah, koperasi syariah, BMT atau LKMS. Penelitian yang dilakukan baru-baru ini oleh Bank Indonesia bekerjasama dengan IPB Bogor, UNDIP Semarang dan Fakultas Ekonomi Universitas Brawijaya untuk kawasan Pulau Jawa, menunjukkan bahwa ada 10,2 persen masyarakat yang menganggap bahwa bank syariah sama saja dengan bank konvensional. Mereka juga beranggapan bagi hasil dan

\footnotetext{
${ }^{26}$ Adlin Sila. "Islamizing Capitalism in Southeast Asia: The Case of Islamic Financial Institution in Indonesia (revisited)". (Artikel tidak diterbitkan), dipresentasikan pada the Seminar Staff in the MA Islamic Studies Programme, Young Indonesian Leader, Leiden University, yang diadakan pada Kamis, tanggal 12 Februari 2009, di gedung Eyckhof 1 / 003C, Universitas Leiden, Belanda.
}

48 Dialog No. 67 Tahun XXXII, Juli 2009 margin keuntungan, sama saja dengan bunga. Mereka mengklaim, bahwa bagi hasil hanyalah nama lain dari sistem bunga.

Pandangan ini juga masih terdapat di kalangan sebagian kecil tokoh Islam yang belum memahami konsep dan operasionalisasi bagi hasil. Akibatnya, di kalangan masyarakat terdapat anggapan bahwa syariah hanya sekedar lipstik dalam lembaga keuangan syariah, karena sistem bagi hasil dalam prakteknya masih dianggap menyerupai sistem bunga pada lembaga keuangan konvensional. Pandangan masyarakat yang awalnya berawal dari pengalaman mereka berhubungan dengan perbankan syariah. Salah seorang sarjana Muslim, Monzer Kaff, sebelumnya mengatakan bahwa aliansi antara praktisi lembaga keuangan syariah dengan ulama (Dewan Syariah) telah memperkenalkan perubahan kosmetik (cosmetic changes) terhadap lembaga dan instrumen, membiarkan struktur dasarnya tidak berubah dari model yang menerapkan bunga (ribawi). Untuk betul-betul Islami, dibutuhkan upaya untuk merancang ulang seluruh sistem menjadi instrumen utama yang berbeda dengan yang ada di lembaga keuangan konvensional. ${ }^{27}$

Bank syariah di Indonesia saat ini umumnya menerapkan produk jual beli, khususnya, jual beli murabahah dan istisna'. Dari sekian produk keuangan bank syariah maka sistem bagi hasil, yaitu mudharabah dan musyarakah, tidak diterapkan secara menyeluruh dalam

${ }^{27}$ Monzer Kaff, The Islamic Economy: Analytical Study of the Functioning of the Islamic Economic System. Plainfield, Indiana: The Muslim Students' Association of the United States and Canada, 1978: 16. 
praktek keuangannya. Pola penyaluran dana bank syariah yang lebih besar bertumpu pada pembiayaan murabahah (akad jual beli) ini mengambil keuntungan berdasarkan margin dari harga barang yang sudah ditambah (cost plus) sebelum dijual kembali (resell) kepada nasabah. Layanan murabahah yang secara praktek menerapkan pengambilan margin dianggap mirip dengan pengambilan bunga yang dilakukan perbankan konvensional.

Selain itu, dalam hal pengajuan kredit perumahan atau kendaraan pada bank atau lembaga keuangan lain yang berbasis syariah, pihak bank menjadikan surat kepemilikan barang (BPKB atau sertifikat rumah) sebagai jaminan. Dengan demikian, sepertinya sama saja dengan bank atau lembaga keuangan konvensional. Terdapat kesan bahwa semua bank atau lembaga keuangan syariah yang menerapkan pengambilan jaminan dianggap belum benar-benar syar'i.

Sebenarnya, akad pembiayaan syariah banyak ragamnya di antaranya adalah jual beli (murabahah) dan sewa (ijarah). Kententuan syariah atas akadakad pembiayaan tersebut di atur oleh fatwa dari Dewan Syariah Nasional (DSN) MUI. Untuk akad murabahah fatwa nomor 04/DSN-MUI/IV/2000 tertanggal 1 April 2000, dan pembiayaan ijarah diatur di dalam fatwa nomor: 09/ DSN-MUI/IV/2000 tanggal 13 April 2000. Sesuai dengan fatwa tersebut dan fatwafatwa lainnya tentang pembiayaan, jaminan (dhaman) dalam pembiayaan syariah dibolehkan. Jaminan dapat berupa barang yang dibeli, barang yang disewa atau barang lainnya yang tidak terkait dengan akad tersebut. Bahkan jaminan milik orang lainpun diperbolehkan. Dalam hal ini tidak ada tumpang tindih akad, karena yang satu akad pembiayaan yang lain adalah akad jaminan, dan akad seperti itu sesuai dengan syariah.

Pada bank konvensional dengan sistem bunga, bank menjanjikan suatu nilai tertentu (biasanya dinyatakan dalam prosentasi suku bunga per tahun) untuk nilai uang yang ditabung. Penentuan suku bunga dibuat dengan pedoman dasar harus selalu menguntungkan untuk pihak Bank. Nilai ini harus dipenuhi bank, tidak peduli apakah bank rugi atau untung besar. Meskipun jumlah keuntungan berlipat ganda saat keadaan ekonomi sedang baik, bank tetap hanya akan membayar sejumlah nilai yang dijanjikan. Model simpanan seperti ini dapat merugikan salah satu pihak. Bank Syariah tidak menjanjikan bonus untuk nasabah tabungan dengan skim wadiah. Bonus dapat diberikan sesuai kondisi keuangan bank syariah setelah perhitungan dan proses bagi hasil antara bank dan nasabahnya.

Menurut data yang dikeluarkan BI, jenis produk keuangan yang ditawarkan kepada nasabah bank syariah sekitar 60 persen dari dana yang bergulir memakai sistem murabahah (jual beli), dan hanya sekitar 35 persen dalam sistem bagi hasil (mudharabah atau musyarakah) (Lihat Tabel 2). Pada kasus perbankan syariah, Abdullah Saeed mengatakan bahwa kebanyakan bank syariah sekarang meninggalkan sistem bagi hasil (mudharabah dan musyarakah) dan lebih memilih sistem Murabahah (jual beli), sebuah sistem yang memastikan untuk terhindar dari risiko macet dan dapat memperoleh keuntungan yang tinggi. Bank-bank ini 
menemukan bahwa sistem Mudharabah dan Musyarakah tidak beroperasional lagi dalam konteks modern ini. ${ }^{28}$ Dengan demikian, sementara perbankan Islam bertujuan untuk menghindari riba dalam bentuknya, modus operasi mereka melalui skema jual beli (Murabahah) sebenarnya sedang mendorong ke bentuk yang secara substansial juga riba. ${ }^{29}$ Namun harus dicatat, meskipun bagi hasil belum diterapkan secara dominan, tetapi praktek bunga sudah bisa dihindarkan secara total. Dan ini setidaknya sudah memuaskan sebagian besar nasabah Muslim yang ingin bertransaksi dengan lembaga keuangan tanpa melanggar aturan agamanya.

\section{Kesimpulan}

Lembaga Keuangan Islam (LKS) seperti Bank Syariah dan BPRS berada dalam kondisi dilematis antara memenuhi aspirasi umat Islam yang menginginkan lembaga keuangan Islam agar lebih mengutamakan kesejahteraan sosial umat Islam dan peningkatan tingkat perekonomian masyarakat miskin dengan keinginan untuk lebih mengedepankan perolehan keuntungan agar lembaga bisa berkembang dan tetap survive. Makanya ketika aspek yang terakhir ini yang menonjol, LKS terkesan sama saja dengan lembaga keuangan konvensional yaitu berorientasi cari untung. Persoalannya, pemasukan dana LKS yang bersumber dari ZIS untuk kemudian disalurkan

${ }^{28}$ Abdullah Saeed. Islamic Banking and Interest: A Study of the Prohibition of Riba and Its Contemporary Interpretation. Brill, Leiden 1999: 76-95.

${ }^{29}$ Mahmoud A. El-Gamal. Islamic Bank dan Regulasi Corporate Governance: A Call for Mutualization. Rice University, Spetember 2005.

50 Dialog No. 67 Tahun XXXII, Juli 2009 sebagai dana sosial ummat sangat minim. Sementara LKS membutuhkan dana atau liquiditas untuk kemudian disalurkan kembali.

Sebenarnya, untuk mencari jalan keluar dari kondisi dilematis ini, beberapa saran bisa ditindaklanjuti oleh LKS yaitu: (1) Bank Syariah dan BPRS harus bisa memetakan kelompokkelompok sosial ekonomi dari nasabahnya; berapa yang berasal dari kelompok menengah atas dan berapa yang di bawahnya. Hal ini diperlukan bagi bank untuk memberikan perbedaan perlakuakn (treatment) kepada nasabahnya dalam hal pemberian kredit dan persyaratannya, (2) Bank Syariah dan BPRS harus memaksimalkan penghimpunan ZIS dari masyarakat, atau melakukan program kemitraan (linkage program) dengan BAZ serta LAZ sehingga dana terkumpul dalam jumlah besar untuk membiayai skema bantuan pinjaman seperti qardhul hasanah. Jenis pembiayaan ini dirancang sebagai pemberian kebajikan, semacam revolving fund, tapi tidak mengharapkan return yang banyak. Bahkan, peminjam hanya mengembalikan pokok pinjaman saja.

Upaya-upaya di atas ini harus didukung oleh pemerintah dalam hal penerbitan regulasi untuk mengatur sumber dana yang berasal dari ZIS ini untuk bisa dikelola pada kegiatankegiatan produktif. Misalnya, pengelolaan dan pendistribusian ZIS sebaiknya dilakukan oleh lembaga keuangan yang sudah berpengalaman. Regulasi ini juga mengatur agar lembaga amil seperti BAZ dan LAZ tidak menyalurkan ZIS langsung ke masyarakat dalam bentuk hibah. Tapi, dalam penyaluran ZIS, sebaiknya 
diberikan kepada LKS agar mengelola dana tersebut untuk usaha secara profesional dengan pendampingan. Dana usaha yang berasal dari ZIS itu agar lebih diutamakan untuk masyarakat yang memiliki jiwa enterpreneurship sehingga lebih mengarah ke usaha-usaha produktif. Sementara untuk aspek konsumtif dikurangi, terbatas kepada kelompok usia tua dan cacat (devable). Dengan cara pengelolaan ZIS semacam ini maka akan tercipta sebuah revolusi sosial karena mengubah individu-individu yang awalnya adalah penerima ZIS menjadi pengusaha-pengusaha yang mampu membayar ZIS di kemudian hari. Ajaran Nabi Muhammad mengenai tangan di atas lebih baik dari tangan yang di bawah bisa terwujud dan dirasakan oleh umat.

Pengambilan margin keuntungan, pembayaran secara kredit dan pensyaratan agunan terutama pada skim Murabahah (jual beli) yang menyebabkan melekatnya anggapan masyarakat bahwa lembaga keuangan syariah sama halnya dengan lembaga keuangan konvensional pada umumnya. Oleh karena itu LKS harus secara tegas mengatakan bahwa nilai tambah yang diberikan bank syariah setiap bulannya kepada nasabah penabungnya berbeda dengan bunga tabungan bank konvensional. Misalnya, dapat dikatakan bahwa dalam bank konvensional, bunga merupakan perwujudan time value of money, atau nilai waktu dari uang. Sementara bonus atau bagi hasil pada bank syariah bukanlah fungsi waktu namun fungsi dari manfaat uang dalam kegiatan usaha. Jadi, wujud bisa sama yaitu ada tambahan (ziyadah) dari uang yang ditransaksikan tapi berbeda dalam hal filosofis dan pendefenisian serta aqadnya.

Terlebih lagi, nasabah LKS umumnya menitipkan uangnya bukan karena motivasi utamanya adalah bonus, tetapi agar dananya aman. Jadi tidak ada masalah jika bank syariah, misalnya, tidak membagi bonusnya, demi untuk menghindari kesan 'bunga'. Masalahnya, seringkali bank syariah agak memaksa diri untuk memberikan bonus agar manfaat bagi nasabah setara dengan tabungan bank konvensional. Hal ini yang membuat nasabah beranggapan bahwa bonus itu sama saja dengan bunga pada lembaga keuangan konvensional.[] 